\title{
Trends of Extreme Temperature and Rainfall Indices for Arid and Semi-Arid Lands of South Eastern Kenya
}

\author{
Samwel N. Marigi' ${ }^{1}$ Andrew K. Njogu'1, William N. Githungo² \\ ${ }^{1}$ Institute for Meteorological Training \& Research, Nairobi, Kenya \\ ${ }^{2}$ Meteorological Office, Kitui County, Kenya \\ Email: drsmarigi@gmail.com
}

How to cite this paper: Marigi, S.N., Njogu, A.K. and Githungo, W.N. (2016) Trends of Extreme Temperature and Rainfall Indices for Arid and Semi-Arid Lands of South Eastern Kenya. Journal of Geoscience and Environment Protection, 4, 158-171. http://dx.doi.org/10.4236/gep.2016.412012

Received: November 21, 2016 Accepted: December 26, 2016

Published: December 29, 2016

Copyright $\odot 2016$ by authors and Scientific Research Publishing Inc. This work is licensed under the Creative Commons Attribution International License (CC BY 4.0).

http://creativecommons.org/licenses/by/4.0/ (c) (i) Open Access

\begin{abstract}
Extreme climate events have profound impacts on economies and livelihoods of many regions of the world. In Kenya, the extreme climate events often have strong impacts on agriculture production systems in the Arid and Semi-Arid Lands (ASALs). A small change in the mean climate condition can cause large changes in these production systems. There is a paucity of information on trends in climate and climate extremes in the country. However, a joint World Meteorological Commission for Climatology/World Climate Research Programme (WCPRP) project on climate Variability and Predictability (WMO CCl/CLIVAR) Expert Team (ET) on Climate Change Detection, Monitoring and Indices has defined 27 core climate indices mainly focusing on extreme events which can be derived through the use of RClimDex Software. In this study, therefore, the RClimDex software has been used to derive climate extreme indices for five stations in the ASALs of South-Eastern Kenya based on climate data for the period 1961 to 2009. The objective was to examine trends in these extremes to aid agricultural planning and practice. These indices have shown decreasing trends in annual rainfall, rainfall intensity and consecutive wet days but increasing trends in consecutive dry days. Steady warming patterns were evident in both the maximum and minimum temperature indices. This paper concludes that indeed significant changes in climate extremes are apparent in the ASALs of the country and recommends a re-thinking of planning and practice of rain-fed agriculture in the ASALs of South-Eastern Kenya.
\end{abstract}

\section{Keywords}

Extreme Climate Events, Climate Indices, Agriculture Systems, ASALs, RClimDex Software 


\section{Introduction}

The Arid and Semi-arid Lands (ASALs) of Kenya are characterised by high climatic variability. This is especially manifest in the erratic nature of seasonal rainfall with respect to onset, quantity, distribution and cessation. This constitutes a major constraint to decision making by smallholder farmers, with respect to production management.

The relatively high frequencies and intensities of extreme climate events, particularly drought and floods, are projected to be exacerbated in the light of climate change [1]. Recent droughts like those in 1983-1984, 1996, 1999-2000, 2005-2006 and 2008-2009 led to large impacts on key sectors of the country's economy. Recurrent droughts generally exacerbate the adversaries and lead to food insecurity. In addition, floods such as those of 1961, 1982-1983, 1997-1998, 2003, 2006, and 2009-2010 also had adverse effects on the country. These climate-related events have the potential to affect the country's national development plans; and retard the strategies for the Sustainable Development Goals (SDGs) and the Government's Vision 2030.

The Kenya Vision 2030 [2] identifies agriculture as one of the six sectors of the economic pillar to address the country's economic growth since it contributes about $24 \%$ of gross domestic product (GDP). Rain-fed agricultural production provides a strong backbone to the overall economy by employing over $85 \%$ of the population. However, about $80 \%$ of Kenya's land is classified as ASALs with very erratic and unreliable rainfall. Further, the frequency and intensity of climate risks (droughts and flash floods) and associated effects on the fragile ASALs environment are anticipated to increase in future due to climate variability and climate change. Use of low and traditional farm inputs, diversity of cultivated crops, poor yield and very limited application of improved soil water management are common features of subsistence economy of small holder farmers in ASALs. A subsistence economy is one that provides sufficient food to last only from one harvest to the next. Therefore, a failure of one harvest means starvation for the ensuing year and shortage of seed for the next cropping season.

The problem of inadequate climate data to enable climate change detection and analysis in the African countries including Kenya continue to inhibit progress in climate vulnerability and impact assessments. Climate indices (indicators of trends) based on extremes can be used as means to communicate climate change impact relations [3] [4] [5]. The WMO expert team on climate change has, therefore, defined several indices for climate change analysis. The Intergovernmental Panel on Climate Change (IPCC), Working Group on Climate Change Detection [6] [7] together with the Joint World Meteorological Commission for Climatology/World Climate Research Programme (WCPRP) project on climate Variability and Predictability (CLIVAR) has helped to bridge this gap by way of developing climate indices that describe climate change in more profound dimensions. The indices are diagnostic tools used to describe the state of a climate system. Climate indices are most often represented by a time series; each point in time corresponding to one index value [8]. Indices are constructed to describe almost any atmospheric event, from number of dry days in a station, to number of extreme cold days, etc. Each of these indices is created with a specific purpose for mea- 
suring and monitoring climate variability and change.

In Kenya, a number of indices are used to detect drought and then subsequently monitor and analyse its occurrence. The simplest indices that have been developed only use precipitation data in the calculations. However, no index has been able to describe the trends in form of length of dry spells. The objective of this study, therefore, was to examine trends in extreme precipitation and temperature indices derived from observed rainfall and temperature for Katumani, Makindu, Kitui, Mwingi and Mutomo meteorological stations in the south-eastern ASALs of Kenya. The information on these trends is critical in decision making with regard to agricultural planning and practice. Attempts have been made by some researchers to derive these indices [9] and [10] for the country. However, these studies have relied on data of only one station from this area of study. Characteristics of these indices for one station may not be quite representative of such a vast area. Location specific characteristics of these indices are necessary for effective planning and decision making. This, therefore, formed the fundamental basis of this study.

\section{Data and Methodology}

Long term daily rainfall, maximum (Tmax) and minimum (Tmin) temperature data for five stations namely Makindu, Katumani, Kitui, (these stations had both rainfall and temperature data), Mutomo and Mwingi (these two stations had only rainfall data) have been used in the study. The ASALs of south eastern Kenya investigated in this study are within the circle indicated in Figure 1. The period of record varied between stations but it is above 35 years for most of the stations. The RHtestsV3 software [11] and [12] using a regression based homogeneity test was used to detect significant discontinuities or shifts in the data sets. RClimDex software [13] was used to calculate extreme indices for the five stations for the period between 1961-2009. The software has an in-build system of checking data quality based on thresholds of relevant parameters and is flexible enough with the capability to compare 27 different standard climatic indicators. Kendall's tau based slope estimator has been used to compute the trends since this method does not assume a distribution for the residuals and is robust to the effect of outliers in the series. If slope error is greater than slope estimate, then the slope estimate cannot be trusted. If $\mathrm{P}$ Value is less than 0.05 , the trend is significant at $95 \%$ level of confidence. Only trends which were found to be statistically significant at $0.05 \%$ level were considered for analysis. A set of 15 indices was selected for this study and their descriptions are provided in Table 1.

\section{Results and Discussions}

\subsection{Trends in Rainfall Extremes}

For rain-fed agriculture economies in ASALs, rainfall is the most important climate element. The dry spell duration indicators have been increasing all over south eastern ASALs of Kenya. Trend of annual total precipitation (PRCPTOT) shows negative slope as depicted in the classical examples for Mwingi and Kitui stations at 5\% significant 


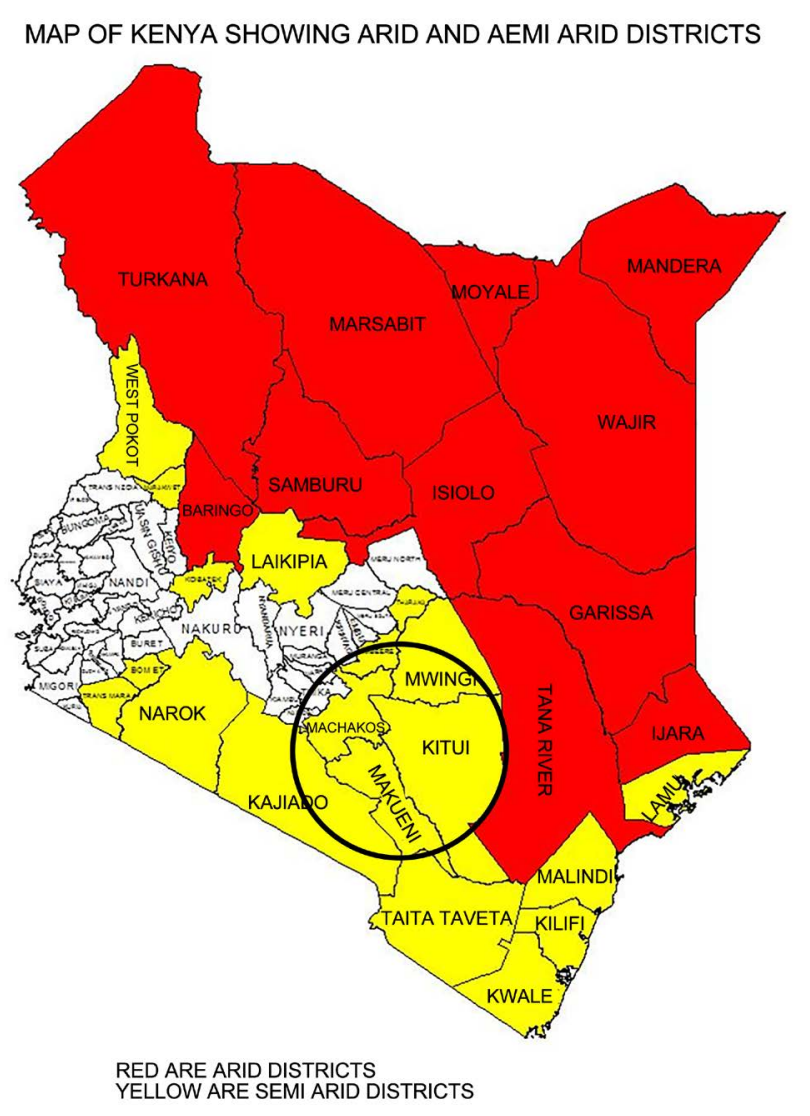

Figure 1. Map of Kenya showing arid and semi arid lands investigated in this study [14].

level (Figure 2 and Figure 3). Consecutive dry days (CDD) are a good indication of the risk of inadequate water for agriculture systems. CDD trends showed increased number of $\mathrm{CDD}$ as depicted in the example provided for Mutomo station at 5\% significant level (Figure 4). Decreasing trend in consecutive wet days (CWD) was evident as indicated in the example provided for Mwingi station at the significant level of 5\% (Figure 5).

Heavy precipitation days is represented by a count of the number of days of heavy precipitation of $10 \mathrm{~mm}$ (R10), $20 \mathrm{~mm}$ (R20) and $30 \mathrm{~mm}$ (R30) of rain per day respectively. Trends of decreasing heavy precipitation were evident as indicated in the examples provided for Kitui station at 5\% significant level (Figures 6-8).

The "Simple Day Intensity Index for rain" (SDII) is the ratio of annual total rainfall to the number of days during the year when rainfall occurred. A decrease in the rain intensity index can result from an increase in rain days while the total amount of annual rainfall remains relatively unchanged. The decrease can also result from a greater increase (smaller decrease) in the number of rainfall days compared to the increase (decrease) in annual rainfall. Similarly, an increase in this indicator could result from a decrease in rainfall days while the total amount of annual rainfall remains relatively unchanged or from a greater increase (smaller decrease) in the annual rainfall compared to the increase (decrease) in the number of rainfall days. Therefore, on average, 
Table 1. List of the 15 climate indices analysed in this paper.

\begin{tabular}{|c|c|c|c|}
\hline ID & Indicator name & & UNITS \\
\hline SU25 & Summer days & $\begin{array}{l}\text { Annual count when TX } \\
\text { (daily maximum) }>25^{\circ} \mathrm{C}\end{array}$ & Days \\
\hline $\mathrm{TN}_{\mathrm{n}}$ & Min Tmin & $\begin{array}{l}\text { Monthly minimum value of daily } \\
\text { minimum temp }\end{array}$ & ${ }^{\circ} \mathrm{C}$ \\
\hline TN10p & Cool nights & $\begin{array}{l}\text { Percentage of days when } \\
\text { TN }<10 \text { th percentile }\end{array}$ & Days \\
\hline TX10p & Cool days & $\begin{array}{l}\text { Percentage of days when } \\
\mathrm{TX}<10 \text { th percentile }\end{array}$ & Days \\
\hline TN90p & Warm nights & $\begin{array}{l}\text { Percentage of days when } \\
\text { TN }>90 \text { th percentile }\end{array}$ & Days \\
\hline TX90p & Warm days & $\begin{array}{l}\text { Percentage of days when } \\
\text { TX }>90 \text { th percentile }\end{array}$ & Days \\
\hline WSDI & $\begin{array}{l}\text { Warm spell duration } \\
\text { indicator }\end{array}$ & $\begin{array}{c}\text { Annual count of days with at least } 6 \\
\text { consecutive days when TX }>90 \text { th percentile }\end{array}$ & Days \\
\hline DTR & $\begin{array}{l}\text { Diurnal temperature } \\
\text { range }\end{array}$ & $\begin{array}{l}\text { Monthly mean difference between } \\
\text { TX and TN }\end{array}$ & ${ }^{\circ} \mathrm{C}$ \\
\hline SDII & $\begin{array}{l}\text { Simple daily intensity } \\
\text { index }\end{array}$ & $\begin{array}{c}\text { Annual total precipitation divided by the } \\
\text { number of wet days (defined as } P R \geq 1.0 \mathrm{~mm} \text { ) } \\
\text { in the year }\end{array}$ & $\mathrm{mm} /$ day \\
\hline R10 & $\begin{array}{l}\text { Number of heavy } \\
\text { precipitation days }\end{array}$ & Annual count of days when $P R \geq 10 \mathrm{~mm}$ & Days \\
\hline R20 & $\begin{array}{c}\text { Number of very heavy } \\
\text { precipitation }\end{array}$ & $\begin{array}{l}\text { days Annual count of days } \\
\text { when } P R \geq 20 \mathrm{~mm}\end{array}$ & Days \\
\hline $\mathrm{R} 30$ & $\begin{array}{l}\text { Number of very heavy } \\
\text { precipitation days }\end{array}$ & $\begin{array}{l}\text { Annual count of days when } \\
\qquad \mathrm{PR} \geq 30 \mathrm{~mm}\end{array}$ & Days \\
\hline $\mathrm{CDD}$ & Consecutive dry days & $\begin{array}{c}\text { Maximum number of consecutive } \\
\text { days with } \mathrm{RR}<1 \mathrm{~mm}\end{array}$ & Days \\
\hline CWD & Consecutive wet days & $\begin{array}{c}\text { Maximum number of consecutive } \\
\text { days with } R R \geq 1 \mathrm{~mm}\end{array}$ & Days \\
\hline PRCPTOT & $\begin{array}{l}\text { Annual total wet-day } \\
\text { precipitation }\end{array}$ & $\begin{array}{l}\text { Annual total PRCP in } \\
\text { wet days }(\mathrm{PR} \geq 1 \mathrm{~mm})\end{array}$ & $\mathrm{mm}$ \\
\hline
\end{tabular}

less daily rain is falling if the index decreases, while more daily rain is falling if the index increases. Trends of decreasing SDII were evident as displayed by the example of Kitui station at 5\% significant level (Figure 9)

\subsection{Trends in Temperature Extremes}

Plants produce maximum growth when exposed to certain threshold values of day and night temperatures. Cumulative temperature values above certain thresholds (which are crop specific) constitute the "Degree Days" which are the determinants of crop growth and development. High temperatures cause increased respiration, sometimes above the rate of photosynthesis. This means that the products of photosynthesis are being used more rapidly than they are being produced. For growth to occur, photosynthesis must be greater than respiration. On the other hand, low temperatures can result in poor growth. The arid and semi-arid lands of Kenya are generally characterised by high day time temperatures. 


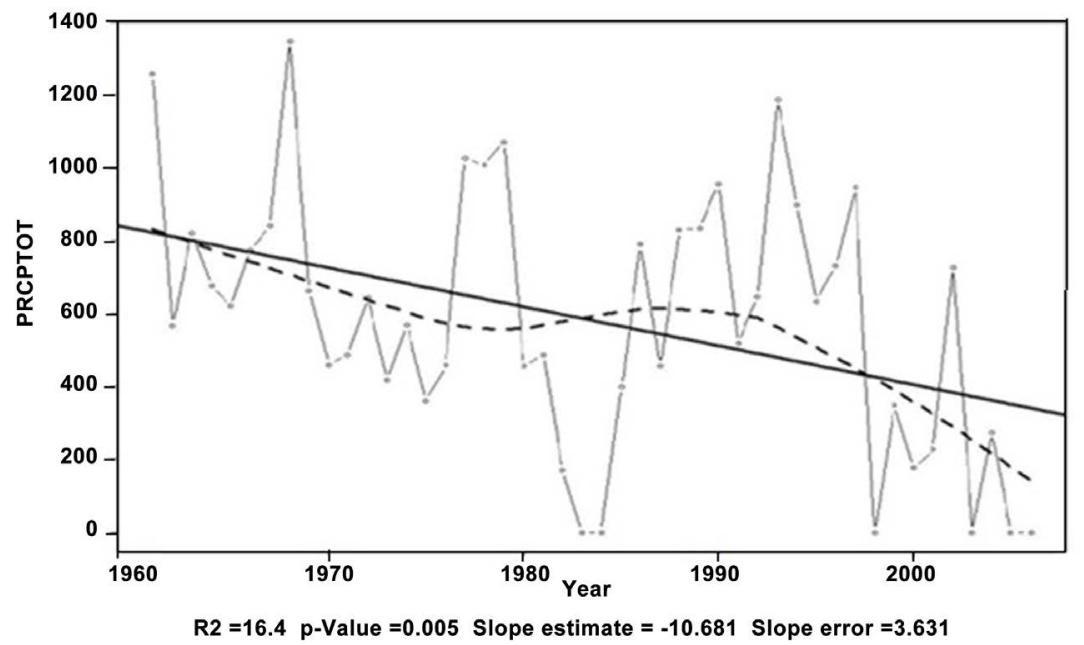

Figure 2. Annual total precipitation in wet days (rain $>1 \mathrm{~mm}$ ) for Mwingi.

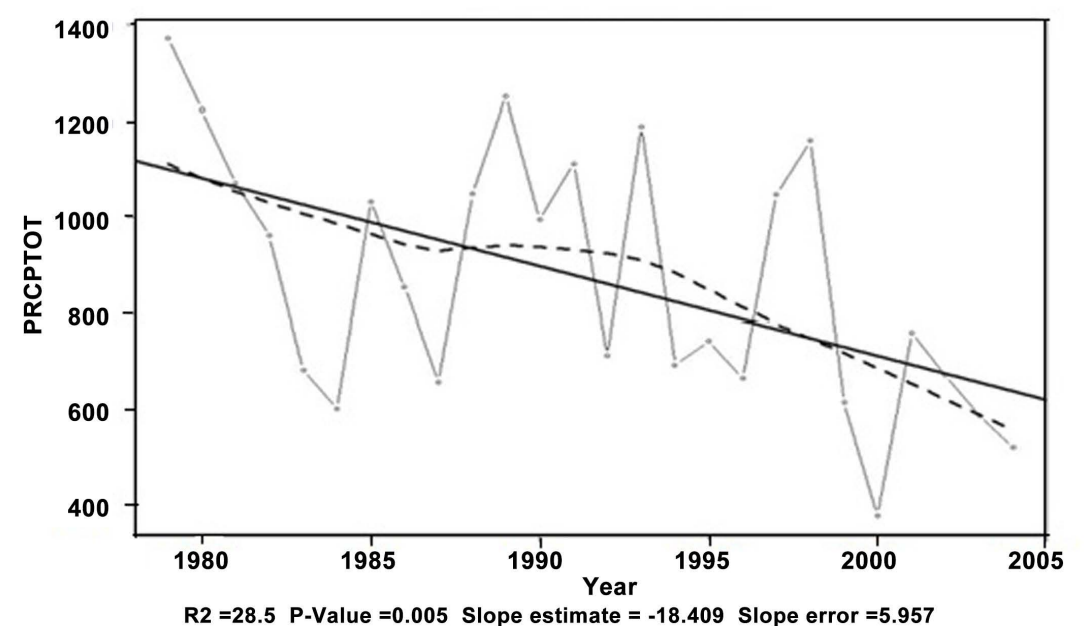

Figure 3. Annual total precipitation in wet days (rain $>1 \mathrm{~mm}$ ) for Kitui.

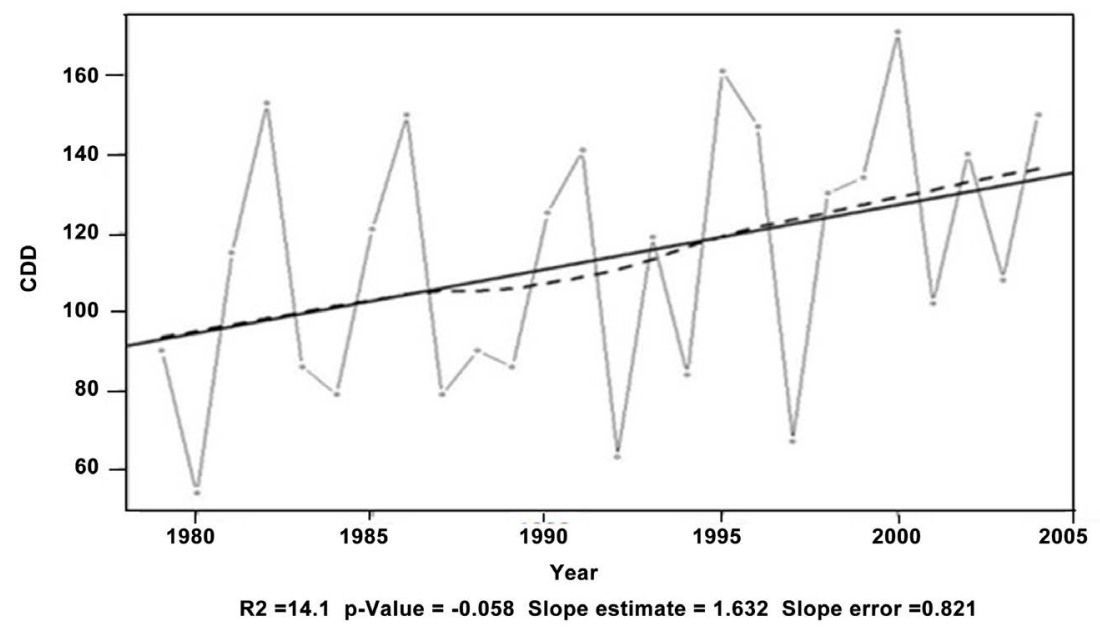

Figure 4. Maximum number of consecutive dry days (rain $<1 \mathrm{~mm}$ ) for Mutomo. 


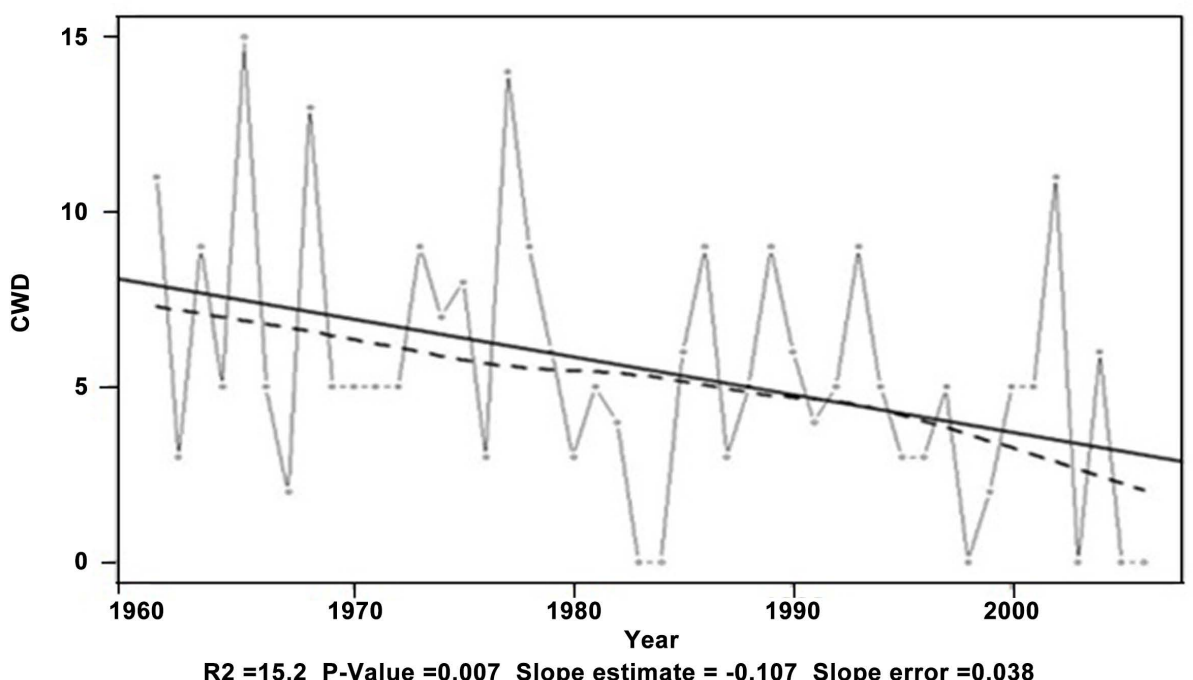

Figure 5. Maximum number of consecutive wet days (rain $>1 \mathrm{~mm}$ ) for Mwingi.

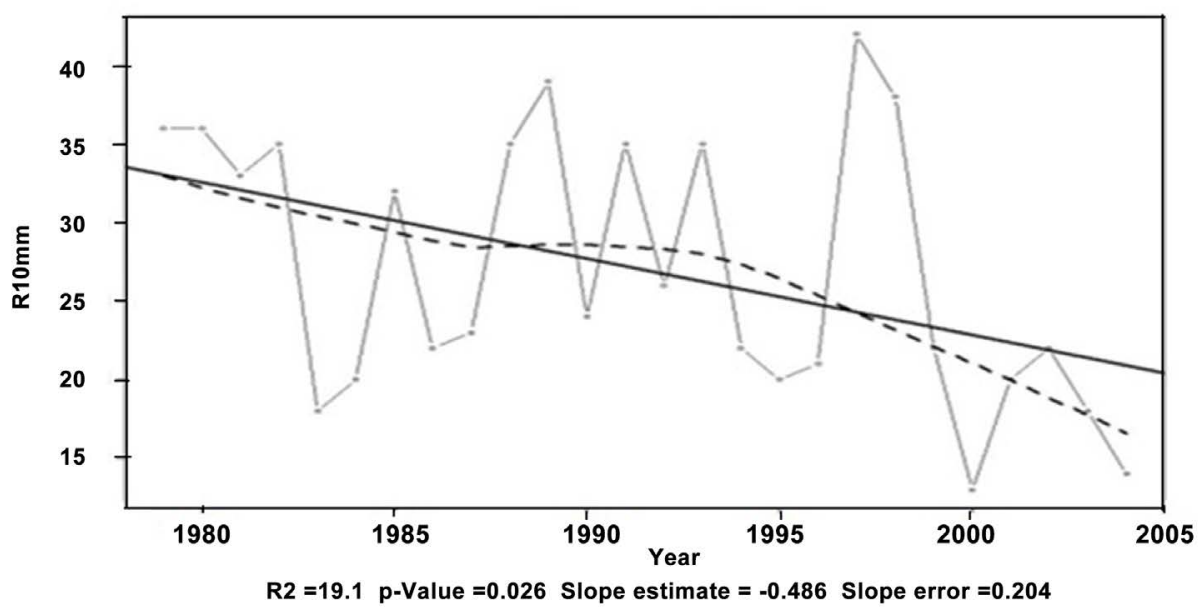

Figure 6. Heavy precipitation days for Kitui (precipitation $>10 \mathrm{~mm}$ ).

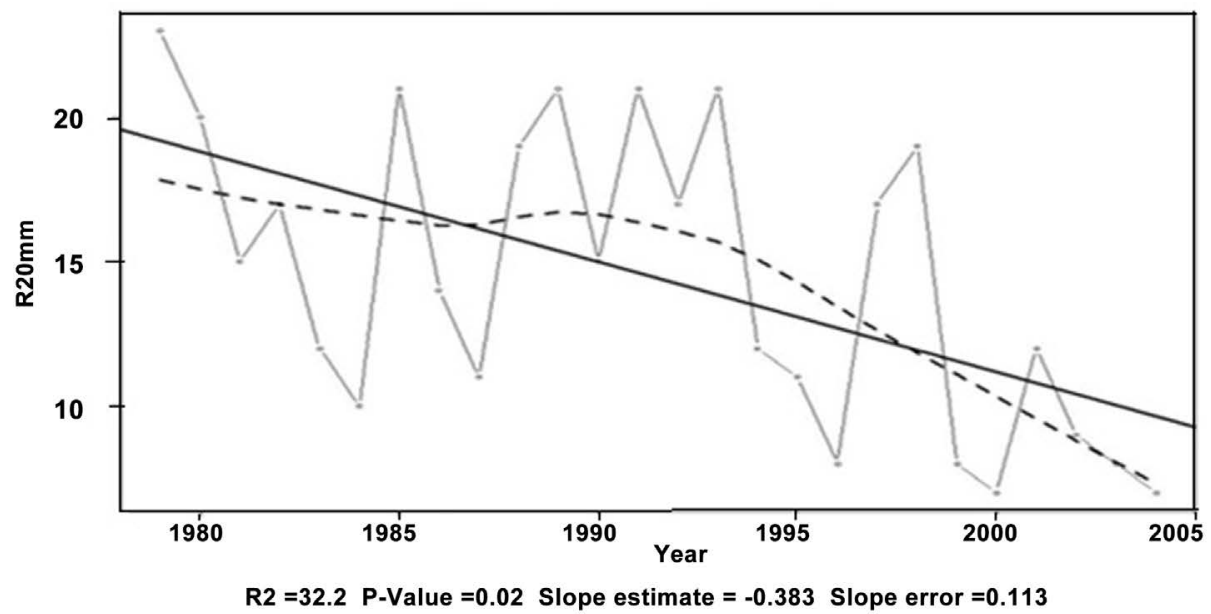

Figure 7. Very heavy precipitation days for Kitui (precipitation $>20 \mathrm{~mm}$ ). 


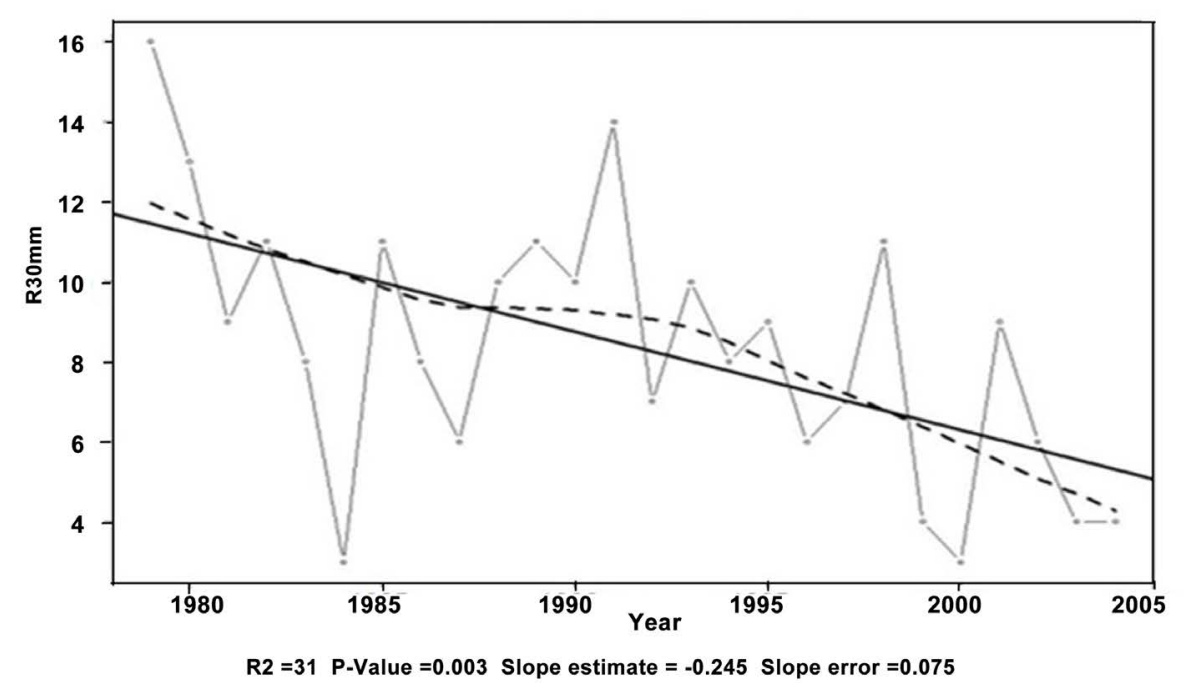

Figure 8. Very heavy precipitation days for Kitui (precipitation $>30 \mathrm{~mm}$ ).

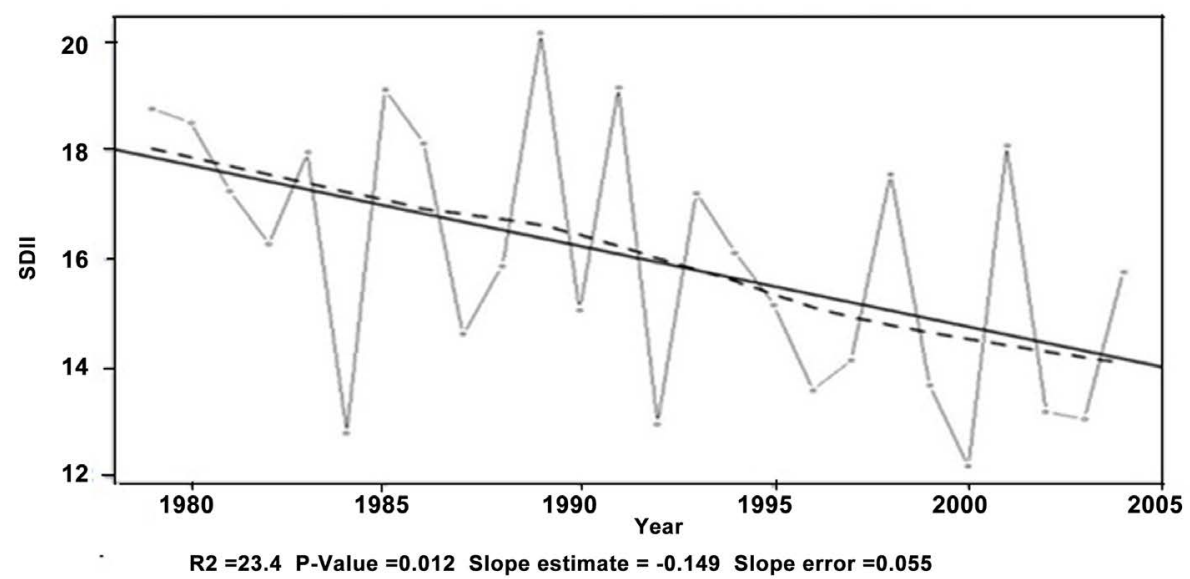

Figure 9. Simple rainfall intensity index for Kitui.

Analysed temperature trends indicated that the number of warm days have continued to increase over south eastern Kenya. Analysis of extreme temperature trend revealed that the days are warmer as indicated by the index "summer days" (SUTmax > $25^{\circ} \mathrm{C}$ ). The examples provided for Katumani and Makindu stations (Figure 10 and Figure 11) clearly show increasing trends of the count of days when temperature exceeds $25^{\circ} \mathrm{C}$ (SU25) at 5\% significant level.

An increasing trend of frequency of days with Tmin $<10^{\text {th }}$ percentile of daily minimum temperature "cold nights" (TNIOP) was also revealed as depicted in the examples provided for Katumani and Kitui stations (Figure 12 and Figure 13) at 5\% level of significance. Regarding trend in days with Tmax $<10^{\text {th }}$ percentile of daily maximum temperature "cold day times", (TXIOP), a decreasing trend was evident. However, for warm day times (TX90P) an increasing trend was revealed as displayed in the examples provided for Katumani and Kitui stations (Figure 14 and Figure 15) at 5\% significant level. In the case of warm nights (TN90P), an increasing trend was evident as presented 


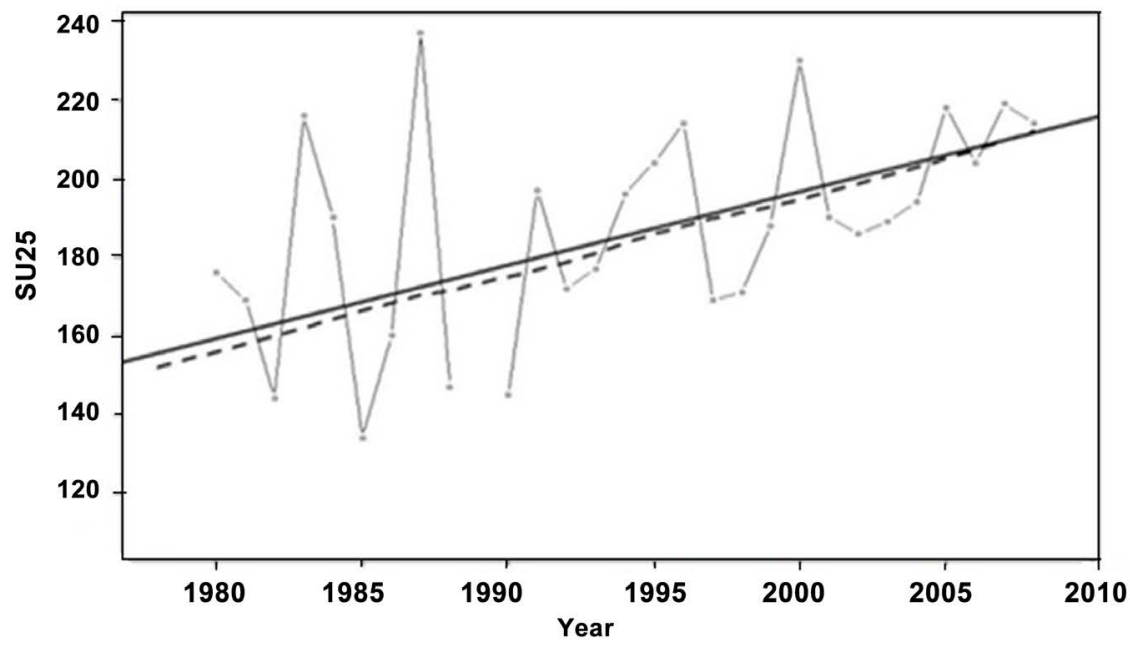

$R 2=30.6$ P-Value $=0.002$ Slope estimate $=1.866$ Slope error $=0.541$

Figure 10. Frequency of days when $\operatorname{Tmax}>25^{\circ} \mathrm{C}$ for Katumani (summer days).

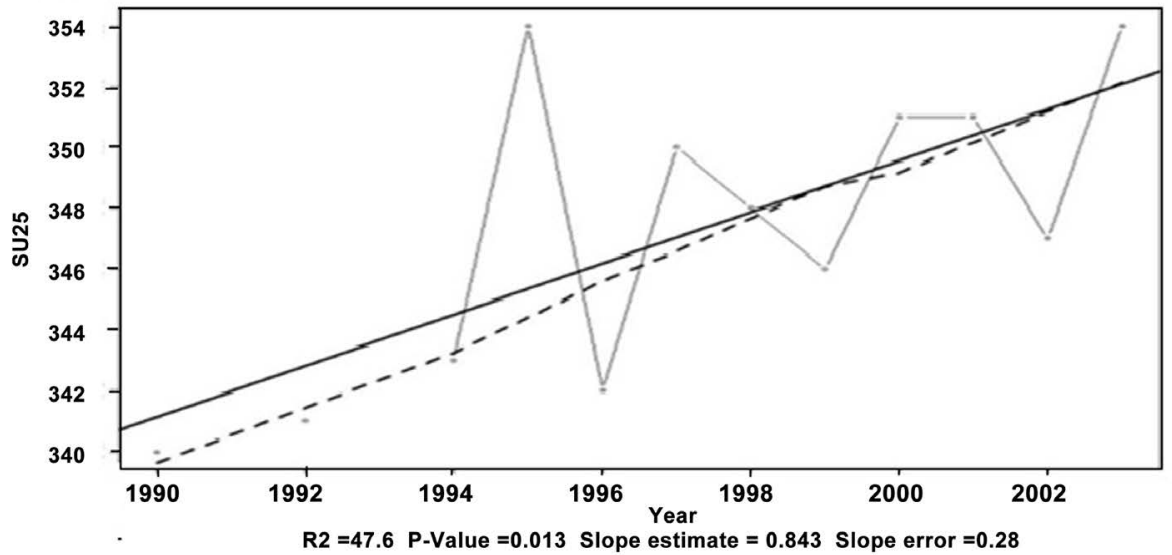

Figure 11. Frequency of days when $\operatorname{Tmax}>25^{\circ} \mathrm{C}$ for Makindu (summer days).

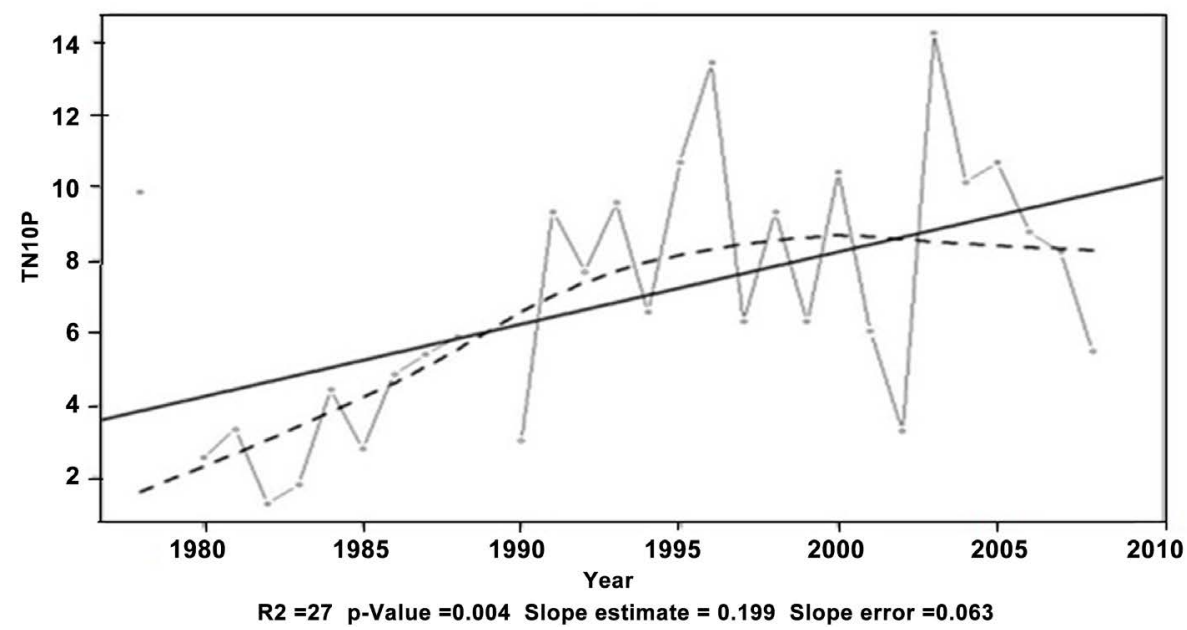

Figure 12. Days with Tmin < 10th percentile of daily minimum temperature (cold nights)Katumani. 


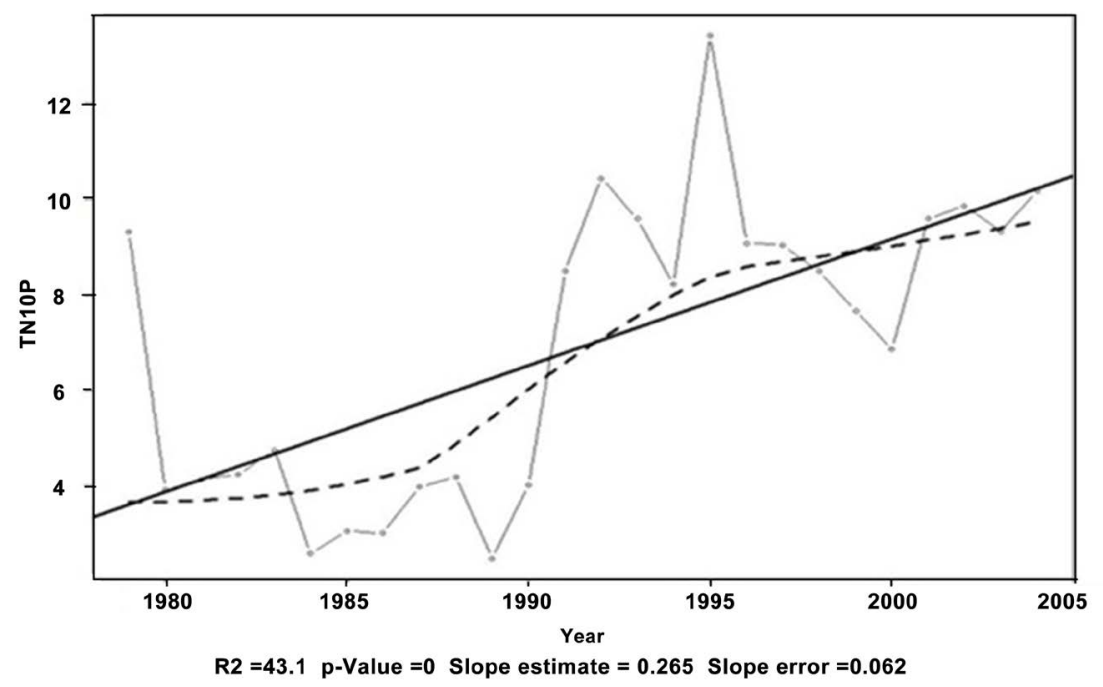

Figure 13. Days with Tmin $<10$ th percentile of daily minimum temperature (cold nights)-Kitui.

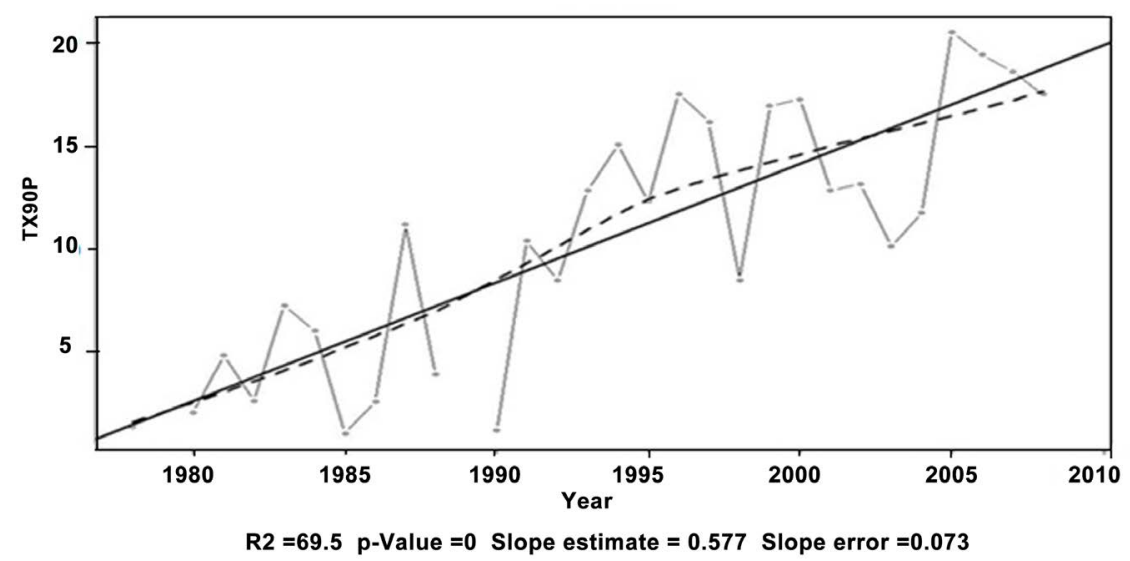

Figure 14. Days with Tmax $>90$ th percentile of daily maximum temperature (warm day-times)-Katumani.

in the examples for Makindu and Kitui stations (Figure 16 and Figure 17) at 5\% level of significance. There is an increasing trend in the annual count of days with at least 6 consecutive days when Tmax > 90th percentile "warm spell duration index" (WSDI), as provided in the example for Katumani (Figure 18) at $5 \%$ significant level. The increasing trend in the WSDI is a good indicator of the persistence of the warm conditions in the region. The mean diurnal temperature range (DTR), on the other hand, indicated decreasing trends as is evident in the example provided for Kitui station (Figure 19) at $5 \%$ significant level.

\section{Conclusion and Recommendations}

\subsection{Conclusion}

These indices show decreasing trend in annual rainfall, rainfall intensity, decreasing 


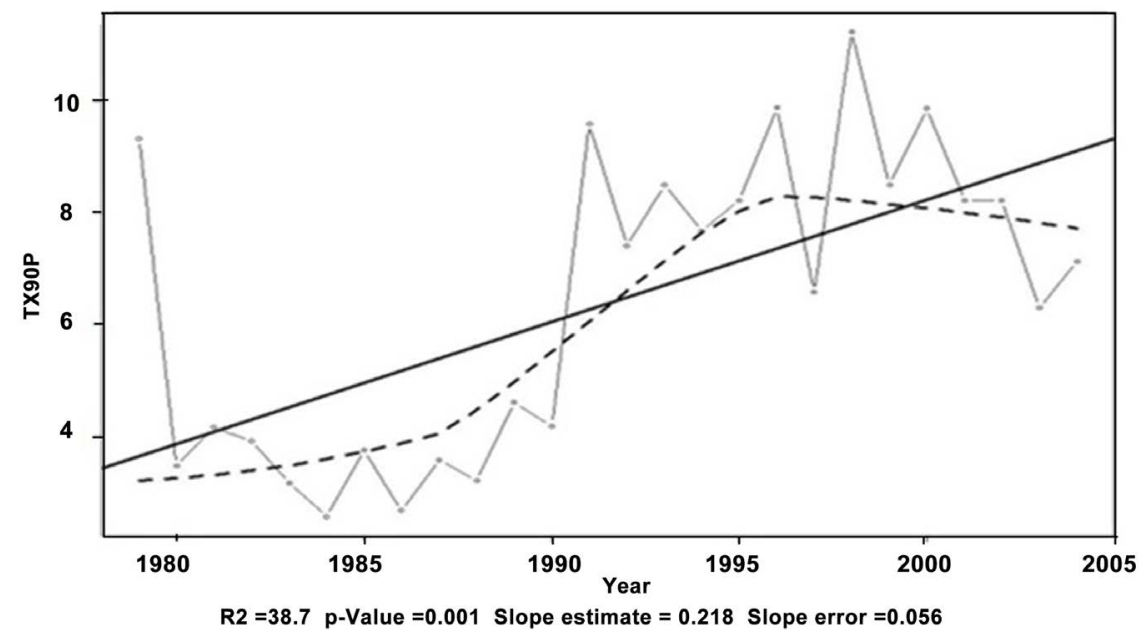

Figure 15. Days with Tmax > 90th percentile of daily maximum temperature (warm daytimes)-Kitui.

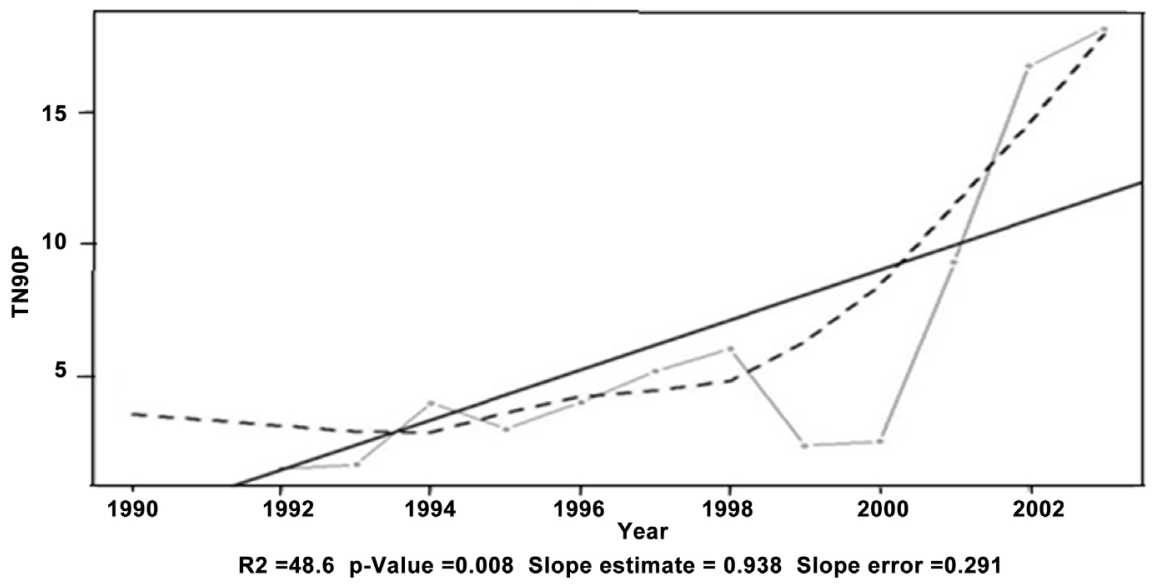

Figure 16. Days with Tmin $>$ 90th percentile of daily temperature (warm nights)-Makindu.

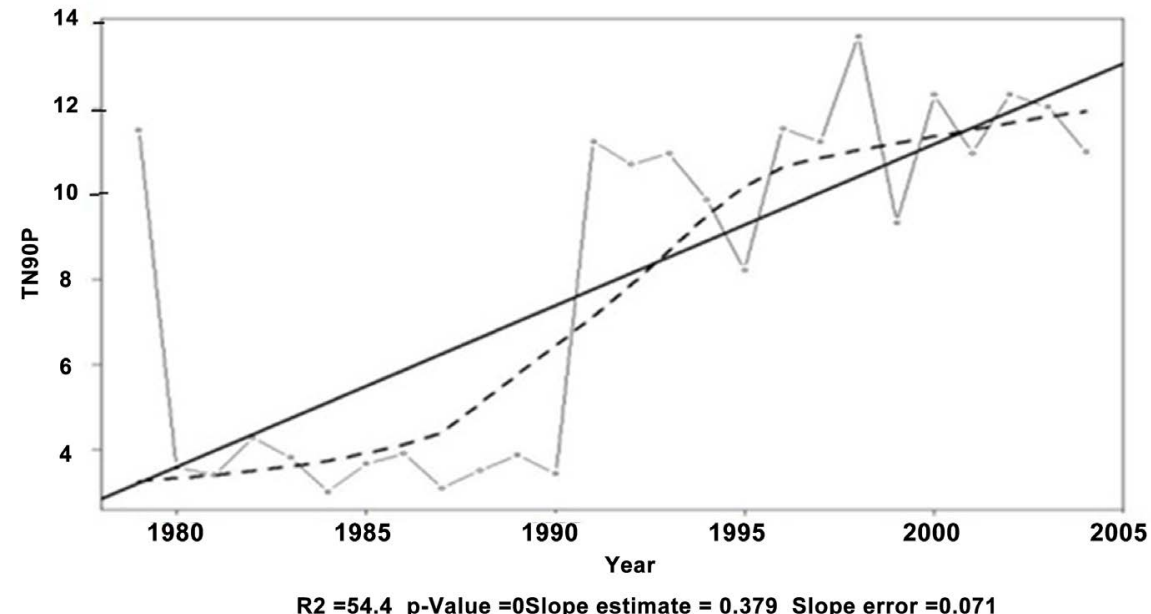

Figure 17. Days with Tmin > 90th percentile of daily temperature (warm nights)-Kitui. 


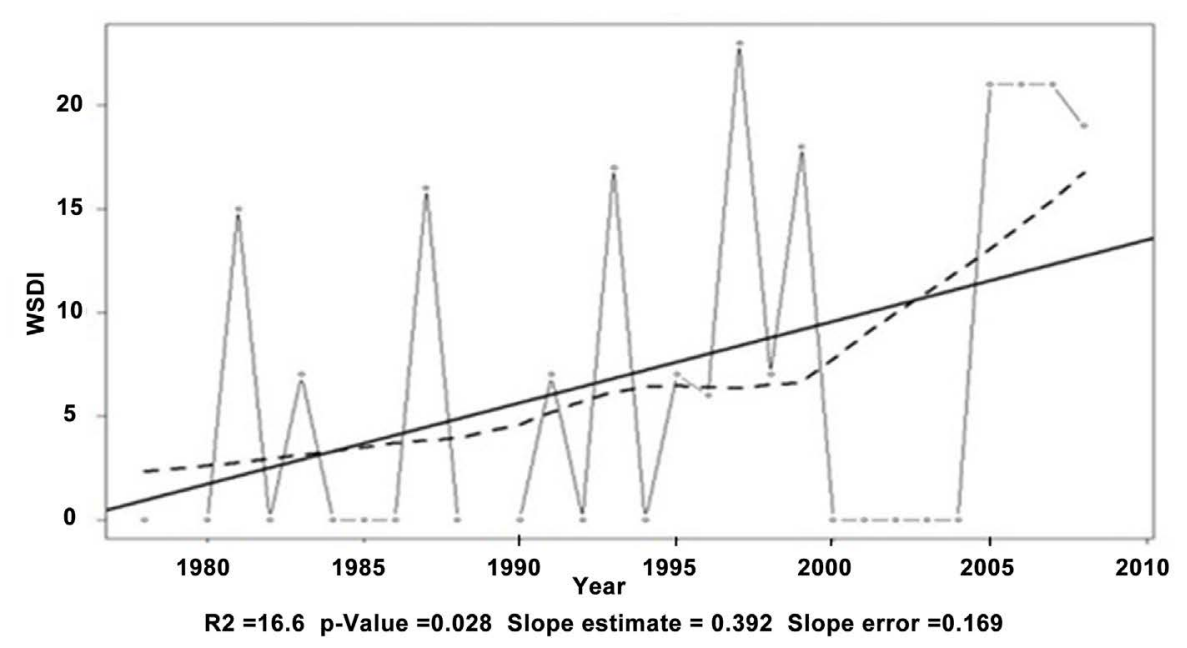

Figure 18. Warm spell duration (days)-Katumani.

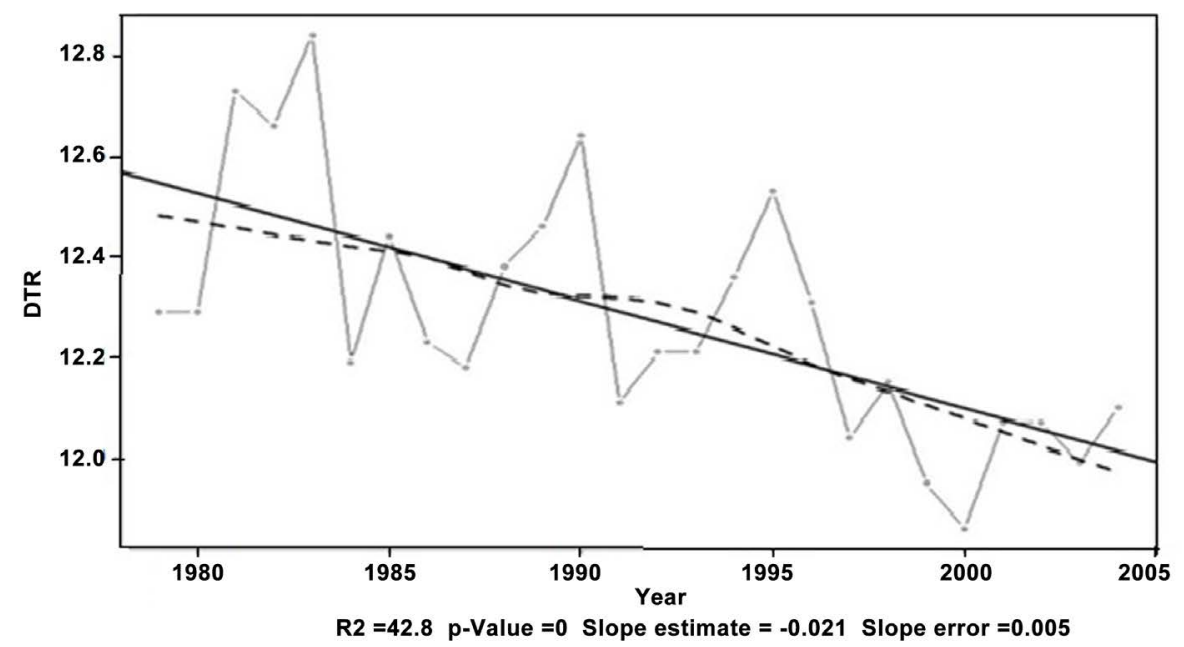

Figure 19. Mean of diurnal temperature range $\left({ }^{\circ} \mathrm{C}\right)$-Kitui.

number of consecutive wet days and increase of consecutive dry days. Steady warming patterns are evident for both the maximum and minimum temperature indices. The diurnal temperature ranges on the other hand depict decreasing trends.

The results of this study are in a general agreement with those obtained by earlier researchers [9] and [10] who used data for one station in the area. However, for this area of study, it is noted that the magnitudes of change of the indices are location specific and therefore the information is more reliable for application in planning and decision making for the specific locations analysed.

The information is important as it reveals that the climate extremes can be a factor which may contribute to the limitations in the ability of society and the area's fragile environment to cope with climate extremes. Agriculture planning and practice in these areas would therefore require careful and full mainstreaming of this information at all stages of decision making. 


\subsection{Recommendations}

The risks associated with extreme weather/climate events have a great impact on the county's socio-economic activities. It is, therefore, essential that all parts of Kenya be examined for evidence of changes in these extremes at the smallest (localized) area as possible and their trends documented. The trends, as observed for the ASALS of South-Eastern Kenya, call for a re-thinking of planning and practice of rain-fed agriculture in the rest of the ASALs of the country.

\section{Acknowledgements}

The authors would like to thank the Kenya Meteorological Department for availing the data used in this study. Our sincere gratitude goes to the two anonymous reviewers whose comments considerably improved the manuscript.

\section{References}

[1] Government of Kenya (GoK) (2010) The National Climate Change Response Strategy. A Kenya Strategy Document, Ministry of Environment and Mineral Resources, 97 p.

[2] Government of Kenya (GoK) (2007) Kenya Vision 2030. Kenya Government Blue Print Development Plan. The Popular Version, Ministry of Planning and National Development, $32 \mathrm{p}$.

[3] Alexander, L.V., Zhang, X., Peterson, T.C., Caesar, J., Gleason, B., et al. (2006) Global Observed Changes in Daily Climate Extremes of Temperature and Precipitation. Journal of Geophysical Research, 111, Article ID: D05109. https://doi.org/10.1029/2005jd006290

[4] Folland, C.K., Karl, T.R., et al. (2001) Observed Climate Variability and Change. Climate Change 2001: The Scientific Basis. In: Houghton, J.T., et al., Eds., Contribution of Working Group I to the Third Assessment Report of the Intergovernmental Panel on Climate Change, Cambridge University Press, Cambridge, 99-181.

[5] Frich, P., Alexander, L.V., Della-Marta, P., Gleason, B., Haylock, M., Klein Tank, A.M.G. and Peterson, T. (2002) Observed Coherent Changes in Climatic Extremes during the 2nd Half of the 20th Century. Climate Research, 19, 193-212. https://doi.org/10.3354/cr019193

[6] Peterson, T.C., Folland, C., Gruza, G., Hogg, W., Mokssit, A. and Plummer, N. (2001) Report of the Activities of the Working Group on Climate Change Detection and Related Rapporteurs. World Meteorological Organization Technical Document No. 1071, World Meteorological Organization, Geneva, 46 p.

[7] Zwiers, F., Cattle, H., Peterson, T.C. and Mokssit, A. (2003) Detecting Climate Change. WMO Bulletin, 52, 37-42.

[8] Wang, X.L. (2003) Comments on "Detection of Undocumented Change Points: A Revision of the Two-Phase Regression Model”. Journal of Climate, 16, 3383-3385. https://doi.org/10.1175/1520-0442(2003)016<3383:CODOUC $>2.0 . C O ; 2$

[9] King'uyu, S.M., Kilavi, M., Omeny, P., Muigai, E. and Njogu, A.K. (2011) Climate Change Indices for Kenya. Journal of Meteorology and Related Sciences, 5, 49-55.

[10] Omondi, P., Awange, L., Forootan, E., Ogallo, L.A., et al. (2013) Changes in Temperature and Precipitation Extremes over the Greater Horn of Africa Region from 1961 to 2010. International Journal of Climatology, 34, 1262-1277. https://doi.org/10.1002/joc.3763

[11] Aguilar, E., Auer, I., Brunet, M., Peterson, T.C. and Wieringa, J. (2003) Guidelines on Cli- 
mate Metadata and Homogenization, WCDMP-No. 53, WMO-TD No. 1186. World Meteorological Organization, Geneva, $55 \mathrm{p}$.

[12] Peterson, T.C., Easterling, D.R., Karl, T.R., et al. (1998) Homogeneity Adjustments of In Situ Atmospheric Climate Data: A Review. International Journal of Climatology, 18, 14931517.

https://doi.org/10.1002/(SICI)1097-0088(19981115)18:13<1493::AID-JOC329>3.0.CO;2-T

[13] Zhang, X. and Feng, Y. (2004) RClimDex User Manual. Climate Research Division, Science and Technology Branch Science and Technology Branch, Environment Canada, 23 p.

[14] Government of Kenya (GoK) (2012) Vision 2030. Development Strategy for Northern Kenya and Other Arid Lands, 114 p.

\section{Submit or recommend next manuscript to SCIRP and we will provide best service} for you:

Accepting pre-submission inquiries through Email, Facebook, LinkedIn, Twitter, etc. A wide selection of journals (inclusive of 9 subjects, more than 200 journals)

Providing 24-hour high-quality service

User-friendly online submission system

Fair and swift peer-review system

Efficient typesetting and proofreading procedure

Display of the result of downloads and visits, as well as the number of cited articles

Maximum dissemination of your research work

Submit your manuscript at: http://papersubmission.scirp.org/

Or contact gep@scirp.org 